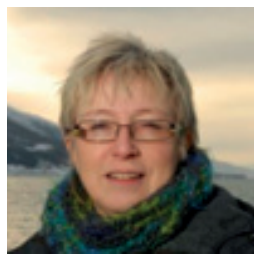

\title{
En pårørendes fortvilelse
}

\section{$\AA$ A være midt i «begivenhetenes sen- trum» når sykdom rammer, er tøft. Man blir så utrolig hjelpeløs når det ikke finnes behandling. Det er når kravene til helsevesenet og legestan- den ikke lenger innfris, at man tyr til hva som helst. I ren fortvilelse.}

Min mann, Jan Henry T. Olsen, fikk konstatert Alzheimers sykdom i en alder av 51 år. Nå er han 53 og all behandling er gitt opp av legene. For det finnes ingen behandling, det er den grusomme beskjeden.

Hver dag må jeg leve med sykdommen, med en mann som jeg ser blir dårligere $\mathrm{og}$ dårligere. Hver dag ser jeg at han klarer færre og færre oppgaver, at han «roter» mer og mer, hallusinerer og blander sammen vårt liv med livet på fjernsynet, er psykisk nedfor og har mistet lysten på livet. Hver dag som jeg ser at han blir dårligere, blir sorgen og fortvilelsen min større. Og det er ingenting jeg kan gjøre. Kontroll på Universitetssykehuset Nord-Norge hvert halvår, nye resepter på Aricept og Ebixa. Som trolig ikke lenger har noen effekt. That's it.

Jeg må derfor innrømme at jeg har «brutt et løfte». Samme dag som vi fortalte til mediene at Jan Henry har Alzheimer sa jeg at vi ikke kom til å springe etter alternative behandlingsmetoder. Jeg tok feil. For noe må man gjøre når man står overfor denne grusomme sykdommen, man kan ikke bare sitte og se på at ens kjære forsvinner gradvis dag for dag uten å foreta seg noe.

Og det vært stor interesse for å hjelpe. Vi făr stadig e-poster, brev og sms-er om mulige behandlingsmetoder - fra folk som tror på alternativ behandling. De bryr seg. De forstår frustrasjonen man føler over å ikke få hjelp. Det er en frustrasjon jeg ikke ser at leger forstår.
På nettsidene til Nasjonalt forskningssenter innen komplementær og alternativ medisin og Nasjonalt informasjonssenter for alternativ behandling finnes noe informasjon. Institusjonene er et tydelig bevis på at behovet for alternative behandlingsmetoder er stor når legevitenskapen kommer til kort.

Dessverre står det lite om Alzheimer. Savnet etter informasjon er stort, ikke bare om alternative behandlingsformer, men også om forskning og nye funn som kan gi litt optimisme. Egentlig hva som helst, stillheten er det verste. I ukeblader og aviser leser jeg om Vivax og Q10 som skal ha hjulpet, jeg har hørt at grønn te kan hindre utvikling av Alzheimer. Men ingen forskningsresultater jeg har kommet over, er slik at jeg helt kan stole på dem. Og jeg spør meg: Hvorfor settes det ikke i gang forskning på slike produkter fra seriøst forskerhold?

Jeg tenker tilbake på vårt møte med helsevesenet da Jan Henrys diagnose skulle stilles. Vi ble møtt seriøst og vennlig, men i ettertid føler jeg at det var som om legene ikke «så oss». I boken vår Skynd deg å elske skriver jeg at det var «som å bli kastet ut på dypt vann uten en tamp å holde i». Akkurat som om det ikke var Jan Henry som pasient og meg som pårørende som var i fokus, men diagnosen. Å stille diagnosen var endepunktet for legene. De forsto ikke at for oss var det da det startet.

Sånt sett føler jeg at engasjementet fra de som driver med alternativ behandling er en trøst. Jeg har ikke tro på at healing kan kure Alzheimers sykdom, men rent logisk kan jeg ikke utelukke at det kan finnes behandlingsmetoder som kan hjelpe. Jo visst finnes det sjarlataner som bare vil tjene penger også der, de finnes jo i alle leirer. Men engasjementet fra hele landet for at Jan Henry skal bli frisk har vært stor, og det har ikke vært leger som har stilt seg fremst i den køen.
Tilbudet vi har i dag består av hjelp til avlastning fra kommunen. Legene har ingenting mer å tilby. Jeg føler at vi fortsatt seiler rundt på havet uten styring. Riktignok med kommunens tilbud som en slags tamp, men skutas skipper, meg, vet ingenting om navigasjon og bølgehøyde. Jeg prøver å dreie roret $\mathrm{i}$ en eller annen retning, så lenge det går. Før eller siden kullseiler vi, og det tidspunktet nærmer seg.

I Dagens Medisin fra 2.4. 2009 skriver man at det mangler forskning på hjernen. «Forskning om hjernen og dens sykdommer er ikke prioritert som en viktig nasjonal oppgave,» skriver de to professorene Nils Erik Gilhus og Leif Gjerstad. «Mange pasienter med hjernesykdommer kan med rette hevde at de ikke får tilbud om den aller beste tilgjengelige behandlingen.» Jeg kan bekrefte at dette er følelsen man sitter igjen med.

Jeg har alltid hatt stor tiltro til leger, legevitenskapen og det norske helsevesenet. Men denne tilliten er nok dalende. Kanskje uten grunn, det er ikke unaturlig at en vitenskap som er så basert på forskning og fakta, blir handlingsslammet når det ikke finnes et svar. Men hvorfor finnes det ikke svar? Hvorfor vet man så lite om en sykdom som ble oppdaget for mer enn 100 år siden?

Hvorfor er det ikke for lengst satt inn ressurser på å finne årsak og behandling for en sykdom som koster samfunnet så mye? Og hvorfor må man i 2010 ty til ukebladartikler om naturmedisiner som har gitt enkelte positive resultater? Samtidig virker lege- og forskermiljøene uinteressert i slike funn.

Det kan virke som om det er lett å sitte på sin høye hest når det virkelige liv leves der nede, fjernt fra en selv!

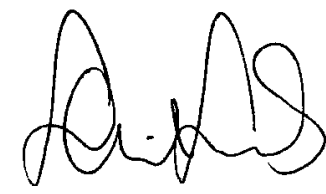

Pregabalin mot fibromyalgi

Leger og sosial ulikhet

- Hepatitt A-smitte ved transfusjon
Lagring av forskningsdata

Legers jobbtilfredshet

Elektronisk utskrivningsrapport 